\title{
Duplicidade de sanções ambientais e o princípio non bis in idem
}

\section{The duplicity of environmental sanctions and the 'non bis in idem' principle}

\author{
Érika Mendes de Carvalho* \\ Sônia Letícia de Méllo Cardoso* \\ Nestor Eduardo Araruna Santiago ${ }^{* * *}$
}

\section{Resumo}

A falta de delimitação entre ilícitos penais e administrativos em matéria ambiental, acompanhada pela total equiparação entre ambos - tal como se depreende do conteúdo dos principais diplomas normativos orientados à proteção do ambiente no plano administrativo e penal -, pode implicar em autêntico bis in idem. Para examinar a questão, será necessário precisar o significado, o fundamento e o alcance do princípio non bis in idem, bem como analisar se a duplicidade de sanções em matéria ambiental importa em infração a esse princípio. Nesse contexto, o artigo pretende, inicialmente, realizar uma abordagem comparativa, analisando a incorporação do non bis in idem ao ordenamento constitucional espanhol, no qual o entendimento doutrinário e jurisprudencial dominante o vincula ao princípio da legalidade. Depois, o artigo se propõe a examinar se o referido princípio pode encontrar respaldo constitucional explícito ou implícito no Brasil e, dessa forma, lançar indagações que possam fomentar o debate

* Doutora e pós-doutora em Direito Penal pela Universidad de Zaragoza. Professora associada na Universidade Estadual de Maringá. Pesquisadora do CNPq. Maringá - PR - Brasil. E-mail: erika. mendes0510@hotmail.com

** Doutora em Direito pela Pontifícia Universidade Católica de São Paulo. Professora adjunta e procuradora jurídica na Universidade Estadual de Maringá. Maringá - PR - Brasil. E-mail: slmcardoso@uem.br

*** Doutor em Direito pela Universidade Federal de Minas Gerais. Professor do Programa de PósGraduação em Direito da Universidade de Fortaleza (Mestrado e Doutorado). Professor do Curso de Graduação em Direito da Universidade de Fortaleza. Professor da Faculdade de Direito da UFC (Graduação). Assessor de Desembargador do Tribunal de Justiça do Estado do Ceará. Fortaleza - CE - Brasil. E-mail: nestoreasantiago@gmail.com 
doutrinário sobre o possível agasalho do princípio ne bis in idem em seara penal ambiental.

Palavras-chave: Crimes ambientais. Sanções ambientais. Princípio non bis in idem.

\section{Abstract}

The absence of delimitation between criminal and administrative injuries in environmental subject, followed by the complete assimilation between them as it can be examined in the most important criminal and administrative laws - can produce an genuine bis in idem. To analyze this point, it is necessary to define the meaning, grounds and limits of non bin in idem principle. In this perspective, this article purposes to examine the bis in idem principle from the constitutional point of view in order to stimulate doctrinal controversy on the non bis in idem principle in environmental criminal area.

Keywords: Environmental crimes. Environmental sanctions. Non bis in idem principle

\section{Introdução}

O exame do conteúdo do princípio non bis in idem em matéria ambiental assume particular relevo, pois é precisamente nesse domínio em que se verifica uma expressiva concorrência de normativas sancionadoras. Trata-se, em linhas gerais, de um princípio geral de direito que veda a duplicidade de sanções - penal e administrativa - nas hipóteses em que seja possível constatar a identidade de sujeito, fato e fundamento (PÉREZ MANZANO, 2005, p. 74).

O princípio non bis in idem apresenta uma face material, conectada com o princípio da proporcionalidade, segundo a qual a aplicação de uma determinada sanção pela prática de certa infração esgota a reação punitiva. Ninguém pode ser sancionado duas vezes pela mesma infração. A aplicação de outra sanção pelo mesmo ramo do direito importaria em uma reação exagerada do ordenamento jurídico, o que significaria uma autêntica ruptura da proporcionalidade. 
Na esfera penal, essa vedação ao bis in idem se conecta com o tema do concurso de crimes. Veda-se a reiteração do ius puniendi estatal, através da duplicidade de sanções penais. Mas essa vedação impede também a imposição plural de sanções penais e administrativas sempre que for constatada a identidade de sujeito, fato e fundamento, em um reconhecimento claro da perspectiva material do non bis in idem. Assim, no que diz respeito à esfera jurídico-penal, o âmbito material do princípio non bis in idem se vincula à problemática do concurso de delitos e à pluralidade de processos penais, bem como à exceção processual da coisa julgada.

Na Espanha, o Tribunal Constitucional (STC 2/1981) reconhece que o princípio non bis in idem se encontra implicitamente vinculado ao princípio da legalidade e tipicidade das infrações (art.25.1, da Constituição espanhola); princípio este que figura como um direito fundamental do réu. É importante analisar o intenso debate jurisprudencial que ocorreu na Espanha, o qual culminou com o reconhecimento constitucional do referido princípio, indiretamente incorporado no conteúdo do princípio da legalidade. Nesse sentido, a STC 221/1997 do Tribunal Constitucional espanhol assevera que "sempre que existir identidade fática, de ilícito penal reprovado e de sujeito ativo da conduta incriminada, a duplicidade de penas é um resultado constitucionalmente proscrito, e isso independentemente de que a origem desse indesejável efeito seja de caráter substantivo ou repouse em considerações de natureza processual".

Por outro lado, no que concerne à vertente processual do non bis in idem, tem-se que ninguém poderá ser julgado duas vezes pelos mesmos fatos ou, segundo alguns, ser submetido a um duplo processo (PÉREZ MANZANO, 2002. p. 75). O Tribunal Constitucional espanhol, em um primeiro momento, entendeu que a atuação da Administração se encontrava subordinada à autoridade judicial (STC 77/1983), propugnando a necessidade de se respeitar a coisa julgada. Assim, sempre que houvesse a intervenção simultânea da jurisdição penal e da atuação administrativa, dever-se-ia conceder prioridade àquela, de modo que seria possível extrair dessa premissa três importantes 
consequências: a) o necessário controle, a posteriori, dos atos administrativos por parte da autoridade judicial, em grau de recurso; b) a impossibilidade de que os órgãos administrativos iniciem procedimentos sancionatórios quando os fatos puderem constituir delito, sendo necessário o prévio pronunciamento da jurisdição penal; c) o inarredável respeito à coisa julgada.

Essa mesma sentença afirmava que quando o ordenamento jurídico admitisse a duplicidade de procedimentos - penal e administrativo -, isso não poderia acarretar apreciações diferentes dos mesmos fatos, mas apenas distintas qualificações jurídicas. A Administração deveria atuar sempre após o pronunciamento da jurisdição penal, observando a determinação fática realizada no âmbito judicial. Portanto, o princípio non bis in idem não impediria necessariamente que o mesmo fato pudesse ser sancionado por distintos ramos do ordenamento jurídico, mas determinaria a prioridade da intervenção da justiça penal e a subordinação da atuação administrativa, quando atuasse a posteriori, à apreciação fática feita pela jurisdição penal. Em todo caso, o princípio non bis in idem impediria que no mesmo ramo do ordenamento jurídico fossem realizados dois procedimentos diferentes orientados à sanção do mesmo fato, sendo possível invocar o referido princípio frente à pretensão de exercer novamente o ius puniendi ou para lograr a anulação do segundo pronunciamento, mas não ante a primeira sanção aplicada (PÉREZ MANZANO, 2002, p.29).

O princípio non bis in idem apresenta, segundo a doutrina espanhola e o Tribunal Constitucional (STC 2/1981), inequívoco fundamento constitucional. Considera-se que ele se encontra intimamente unido ao princípio da legalidade e tipicidade das infrações penais e administrativas, constante do artigo 25.1 da Constituição espanhola. Além disso, sustenta-se que a vedação do bis in idem deriva do artigo 10.2 - dado que está prevista nos tratados internacionais sobre direitos humanos (STS, de 6 de maio de 1987) - e do artigo 9.3 - principio da segurança jurídica (STS, de 26 de fevereiro de 1993) -, ambos da Constituição espanhola, bem como do princípio da proporcionalidade (STC 154/1990) e do direito ao devido processo legal, consagrado no 
artigo 24.2, CE (STS, de 23 de dezembro de 1992). Uma vez que o referido princípio se conecta ao princípio da legalidade e da tipicidade das infrações, possui status de direito fundamental. Por conseguinte, sua aplicação é direta e imediata, não sendo necessário expresso reconhecimento legal (SERRANO TÁRRAGA; SERRANO MAÍLLO; VÁZQUEZ GONZÁLEZ, 2009, p. 113).

Todavia, existe na Espanha um sólido histórico jurisprudencial e doutrinário orientado à interpretação do princípio non bis in idem. De fato, tanto a doutrina espanhola como a jurisprudência ordinária e constitucional se dedicaram, especialmente nas últimas três décadas, a examinar o conteúdo, fundamento e alcance do princípio em apreço, considerado um dos fundamentos do direito penal moderno. A ausência de um reconhecimento constitucional expresso não impediu que o Tribunal Constitucional espanhol dedicasse particular atenção à elaboração do princípio non bis in idem, impulsionado pelas doutrinas administrativa e penal.

De início, cabe salientar que o princípio non bis in idem tem como âmbito de aplicação o ordenamento sancionador como um todo, ou seja, estende-se ao direito penal e ao direito administrativo sancionador (GÓRRIZ ROYO, 2004, p. 193). Desse modo, limita o ius puniendi estatal tanto no plano interno de cada ramo do ordenamento sancionador direito penal e direito administrativo sancionador - como na esfera externa, isto é, quando ambos os setores do ordenamento atuam simultaneamente na tutela do mesmo bem jurídico (GÓRRIZ ROYO, 2004, p. 193). E isso porque, como corretamente se assinala, a vedação geral ao bis in idem se vincula "à unicidade do Ius Puniendi Estatal, qualquer que seja a multiplicidade de planos nos quais este se distribua, que sempre serão reciprocamente excludentes" (MUÑOZ CLARES, 2006, p. 269-270). Nessa perspectiva, o princípio non bis in idem apresenta especial significado quando o ordenamento jurídico-penal e o ordenamento administrativo sancionador se orientam à proteção do ambiente. De fato, com acentuada frequência, é possível constatar que diversos preceitos normativos apresentam idêntico conteúdo e muitas vezes tais setores intervêm simultaneamente, com vistas a sancionar as mesmas condutas. 
Notadamente após o advento do Código Penal de 1995, várias sentenças do Tribunal Constitucional espanhol se dedicaram a precisar o conteúdo e o alcance do princípio non bis in idem, especialmente em sua vertente processual. Esta, conforme já destacado, proíbe que alguém possa ser julgado duas vezes pelos mesmos fatos, de modo que essa face do princípio se vincula diretamente à garantia processual do devido processo legal (art. 24, Constituição Espanhola - CE; art.5 , LIV, Constituição da República Federativa do Brasil - CF) e com o princípio do juiz natural (art. $5^{\circ}$, LIII, CF). O ordenamento jurídico brasileiro, a exemplo do espanhol, não consagra expressamente tal princípio. Todavia, diferentemente da doutrina e jurisprudência espanholas, no Brasil, poucos se ocupam em proceder à necessária delimitação do citado princípio e harmonizá-lo com a regra de preferência da jurisdição penal. Por essa razão, revela-se importante conhecer o caminho trilhado pela jurisprudência e doutrina espanholas no processo de incorporação do princípio do non bis in idem como corolário do princípio constitucional da legalidade.

Em seara penal ambiental, tem-se como oportuna a análise do papel do princípio non bis in idem não apenas em virtude do fenômeno de reenvio à normativa administrativa na configuração dos ilícitos penais, mas, principalmente, em razão da preocupante identidade entre o conteúdo dos delitos e das infrações administrativas, conforme se constata ao examinar as normativas vigentes (Lei 9.605/98 e Decreto $6.514 / 08)$.

\section{Fundamento e pressupostos do princípio non bis in idem: uma abordagem comparativa}

No Brasil, tanto o fundamento quanto o âmbito de aplicação do princípio non bis in idem ainda demandam ingente esforço doutrinário. De modo geral, perfilha-se o princípio da independência da potestade administrativa, que conduz à plena compatibilidade entre pena e sanção administrativa. Apenas na esfera penal é possível extrair referências legais indiretas à vedação ao bis in idem, tal como se depreende do 
caput do artigo 61 do Código Penal ("são circunstâncias que sempre agravam apena, quando não constituem ou qualificam o crime"), do artigo 15 ("são circunstâncias que agravam a pena, quando não constituem ou qualificam o crime") e do artigo 58 ("as penalidades previstas neste artigo serão aplicadas se do fato não resultar crime mais grave"), ambos da Lei 9.605/98, aplicáveis aos delitos ambientais.

$\mathrm{Na}$ atualidade, porém, a possibilidade de imposição conjunta de sanções penais e administrativas pela prática de um mesmo fato é aventada como exemplo inconteste de inadmissível bis in idem (PRADO, 2012). A ausência de uma delimitação precisa entre os domínios da jurisdição penal e da administrativa em seara ambiental contribui para que se fomente uma situação de grande insegurança no que concerne à admissibilidade e à legitimidade constitucional da imposição de dupla sanção pela realização de um mesmo fato. Em princípio, em face do texto constitucional (art. 225, § $3^{\circ}, \mathrm{CF}$ ) e da própria Lei 9.605/98, facultase a imposição cumulativa de penas e sanções administrativas "por condutas e atividades lesivas ao meio ambiente".

$\mathrm{Na}$ Espanha, o rechaço à duplicidade de sanções penais e administrativas pela prática de uma mesma conduta se inicia timidamente na jurisprudência do Tribunal Supremo (STS, de 11 de maio de 1965 e de 7 de maio de 1978) e também na doutrina ${ }^{1}$, como oposição a toda uma sólida orientação anterior que defendia a natureza independentemente das referidas sanções e a compatibilidade da coexistência entre a potestade judicial e a administrativa sancionadora (GÓRRIZ ROYO, 2004). Foi, porém, a sentença do Tribunal Constitucional n. 2, de 30 de janeiro de 1981, que concluiu que, apesar da falta de referência constitucional expressa ao non bis in idem, este estaria conectado aos princípios da legalidade e da tipicidade (art. 25, CE). A importância desse pronunciamento reside não apenas no fato de erigi-lo ao patamar de direito fundamental, mas também de estender sua aplicação a todo o

Assim, por exemplo, Cuerza Riezu (1991, p. 840); Martín Retortillo Baquer (1971, p. 16) e García de Enterría (1976, p. 415). 
ordenamento sancionador (penal e administrativo). Além disso, indicou os pressupostos básicos para sua apreciação concreta, a saber: identidade de sujeito, fato e fundamento. Com efeito, a partir da STC n. 2/1981, tem-se a proclamação de exigência da denominada tríplice identidade - representada pelas identidades de sujeito, de fatos praticados e, especialmente, de conteúdo do ilícito - para impedir a aplicação de dupla sanção (penal e administrativa). Entretanto, estabelece-se como requisito negativo à aplicação do princípio non bis in idem a constatação de uma relação de sujeição ou de supremacia especial. Por conseguinte, embora verificada a tríplice identidade, seria cabível a imposição de dupla sanção sempre que existisse uma relação de supremacia especial da Administração justificando o exercício do ius puniendi por parte da justiça penal e da potestade sancionadora da Administração².

Posteriormente, matizando esse pronunciamento inicial, o Tribunal Constitucional agregou como fundamento do princípio non bis in idem - em sua perspectiva material - o princípio da proporcionalidade (STC 154/1990; STC 177/1999), o qual determina que a sanção administrativa e a pena cominada e/ou aplicada se ajustem à gravidade da infração administrativa e/ou delito perpetrado. Nesse sentido, a imposição simultânea de uma pena e uma sanção administrativa a um mesmo sujeito, devido à prática de uma mesma infração, seria uma reação excessiva por parte do ordenamento jurídico, que importaria em violação ao princípio de proporcionalidade ${ }^{3}$.

Nessa linha, cabe ressaltar que a dicção constitucional do princípio da legalidade no ordenamento penal pátrio impede, em princípio, que

2 Sobre a imprecisão da noção de "relação de supremacia ou sujeição especial" para afastar a aplicação do princípio non bis in idem às sanções disciplinares - espécie do gênero sanções administrativas -, afirma-se, com razão, que "a falta de aplicação - ou a aplicação 'desvirtuada"” dos princípios da reserva legal e do non bis in idem "obedece à consideração de que entre a infração penal e a infração disciplinar não se dá uma mera diferenciação quantitativa ou de grau, mas uma distinção qualitativa ou de essências. Diferença qualitativa esta que ensejaria a configuração do ilícito disciplinar não como um minus, mas como um aliud em relação ao ilícito penal." (HUERTA TOCILDO, 2002, p. 45)

3 Assim, na doutrina espanhola, entre outros, García Rivas (1996); Pérez Manzano (2002); Górriz Royo (2004, p. 200-201). 
este figure como fundamento do princípio non bis in idem ("não há crime sem lei anterior que o defina, nem pena sem prévia cominação legal", art. $\left.5^{\circ}, \mathrm{XXXIX}, \mathrm{CF}\right)$. Todavia, a exigência de proporcionalidade entre delitos e penas e entre infrações e sanções administrativas poderia, em tese, oferecer supedâneo à vedação ao bis in idem. Entretanto, tal princípio carece de reconhecimento constitucional explícito (PRADO, 2011, p. 175), o que não impede vincular, no Brasil, a exigência de non bis in idem à vedação constitucional expressa às penas cruéis (art. $5^{\circ}$, $\mathrm{XLVI}, e, \mathrm{CF}$ ) e ao princípio da individualização da pena (art.5 $5^{\circ} \mathrm{XLVI}$, $\mathrm{CF})$.

\section{2 Âmbito de aplicação e requisitos do princípio non bis in idem no ordenamento espanhol}

A determinação do âmbito de aplicação do princípio non bis in idem se relaciona diretamente com a questão dos limites à potestade sancionadora da Administração. Na Espanha, a sentença do Tribunal Constitucional n. 77/1983 pronuncia-se pela preferência do ordenamento jurídico-penal em relação ao ordenamento administrativo sancionador. Ou seja, a manifestação sancionadora da Administração se subordina ao pronunciamento judicial. Segundo a referida sentença, havendo colisão entre uma atuação jurisdicional e outra administrativa, resolvese a favor da primeira. Essa premissa inicial acarreta importantes consequências, a saber: a possibilidade de controle judicial a posteriori dos atos administrativos, em grau de recurso; a vedação de instauração de procedimento administrativo, quando a conduta for prevista como crime, enquanto não houver pronunciamento da jurisdição penal; o respeito à coisa julgada. Pois bem, a regra da preferência da jurisdição penal se baseia no princípio de subordinação da Administração ao Poder Judiciário, que, por sua vez, encontra supedâneo no denominado princípio da unidade do ordenamento sancionador estatal. De acordo com este, "o ius puniendi é um supraconceito, do qual são manifestações a potestade punitiva penal e a sancionadora administrativa" (GÓRRIZ ROYO, 2004, p. 204). O princípio da unidade do direito sancionador é 
acatado pela quase totalidade dos ordenamentos jurídicos e, mesmo para aqueles que não o consagrem, "seria excessivo conceber, dentro do mesmo ordenamento, uma espécie de compartimentos estanques, incomunicáveis, constituídos pelas normas penais e pelas disciplinares" (VIVES ANTÓN, 1995, p. 363). O ius puniendi se manifesta, portanto, em duas esferas distintas e complementares, que não se encontram em plano de igualdade, e confere primazia à jurisdição penal. Com esse proceder, assegura-se, em tese, o respeito ao princípio non bis in idem - sob a perspectiva processual e material -, na medida em que a exigência de anterioridade da intervenção penal na apreciação de uma mesma conduta seria um obstáculo à pluralidade de processos e, consequentemente, à duplicidade de sanções.

Entretanto, mesmo o reconhecimento doutrinário e jurisprudencial dos princípios da unidade do ordenamento jurídico e da primazia da jurisdição penal sobre a administrativa não impediram, na Espanha, a ocorrência de diversas situações de dupla imposição de sanções pela prática dos mesmos fatos, especialmente nas chamadas "matérias 'limítrofes' entre o direito penal e o direito administrativo sancionador" (GÓRRIZ ROYO, 2004, p. 206). Tais hipóteses foram apreciadas pelo Tribunal Constitucional espanhol em grau de recurso e algumas dessas decisões superiores representaram uma relativização da regra de prevalência da jurisdição penal, o que significou uma clara mudança na orientação jurisprudencial até então existente. Posto que a configuração do princípio non bis in idem se vinculava à regra da preferência da jurisdição penal, seu âmbito de aplicação sofreu inequívoca transformação, sobretudo com as sentenças 177/1999 e 152/2001 do Tribunal Constitucional espanhol.

A primeira delas (STC 177/1999) reconhece a identidade subjetiva exigida como requisito à constatação do bis in idem entre uma pessoa física (condenada por um delito) e uma pessoa jurídica (condenada por uma infração administrativa). Em ordenamentos jurídicos que - como o brasileiro o faz em matéria ambiental - consagrem a responsabilidade penal da pessoa jurídica, sem prejuízo da responsabilidade das pessoas físicas - autoras, coautoras ou partícipes do mesmo fato $\left(\operatorname{art} .3^{\circ}\right.$, parágrafo 
único, Lei 9.605/98) -, não será possível aferir a identidade subjetiva indispensável ao reconhecimento do bis in idem. Por conseguinte, não há bis in idem quando, pelos mesmos fatos, condena-se na esfera penal a pessoa jurídica e, no âmbito administrativo, a pessoa física, dada a ausência de identidade subjetiva. Todavia, segundo a legislação penal ambiental brasileira, o bis in idem é expressamente admitido em relação às pessoas jurídicas, pois o artigo $3^{\circ}$, caput, da Lei 9.605/98, dispõe que estas "serão responsabilizadas administrativa, civil e penalmente conforme o disposto nesta Lei".

Pois bem, não foi, porém, o reconhecimento equivocado da identidade subjetiva entre pessoa física e jurídica pela STC 177/1999 que acarretou, na Espanha, em uma verdadeira alteração do âmbito de aplicação do princípio non bis in idem e sua relação com a regra da preferência da jurisdição penal. A referida sentença, ao apreciar a possível vulneração do princípio, concluiu que a aplicação anterior de uma sanção administrativa à pessoa jurídica impedia a posterior condenação penal de seu diretor por um delito ambiental. Por um lado, a condenação da pessoa física pela jurisdição penal de primeira instância, ao ser posterior ao exercício da potestade administrativa, ensejava o reconhecimento de infração à regra da preferência da jurisdição penal. Contudo, se assim o fizesse, o Tribunal Constitucional espanhol vulneraria o princípio non bis in idem em sua vertente material, visto que haveria duplicidade de sanções pelos mesmos fatos (a administrativa, já aplicada, e a penal). Diante desse conflito, o Tribunal Constitucional espanhol reforçou que a vedação constitucional ao bis in idem representava um direito fundamental do cidadão "frente a uma desproporcional reação punitiva" por parte dos poderes legitimados para o exercício do ius puniendi estatal. Posto isso, conferiu primazia ao aspecto material do bis in idem - vedação da cumulação de sanções pela prática do mesmo fato -, em detrimento da regra de prevalência da jurisdição penal em relação à administrativa. Por consequência, concluiu na STC 177/1999 que a eventual inobservância, por parte da Administração sancionadora, da regra legal que confere preferência à jurisdição penal não podia acarretar uma reação punitiva desproporcional, isto é, redundar em duplicidade 
de sanções,

o que significa que a preferência da jurisdição penal sobre a potestade administrativa sancionadora deve ser entendida como uma garantia do cidadão complementar de seu direito de não ser sancionado duas vezes pelos mesmos fatos, e nunca como uma circunstância limitativa da garantia que implica aquele direito fundamental. ${ }^{4}$

Em síntese, o respeito à vertente processual do princípio non bis in idem - consubstanciada na impossibilidade de duplo processo sancionador e vinculada à regra da preferência jurisdição penal sobre a administrativa - não pode ensejar violação de sua faceta material - vedação da aplicação de duas sanções pelo mesmo fato -, o que ocorreria no caso em apreço se fosse reconhecida a prioridade da jurisdição penal, uma vez que a sanção administrativa já havia sido imposta.

Esse posicionamento do Tribunal Constitucional espanhol motivou algumas críticas doutrinárias e, entre elas, merece destaque a que sustenta que a observância da regra de prevalência da jurisdição penal não é consequência, como assevera a STC 177/1999, do princípio non bis in idem, nem este daquela. A regra de preferência da jurisdição penal encontra seu fundamento na necessária subordinação da Administração ao Poder Judiciário, o que representa uma garantia ao cidadão de que as decisões administrativas são passíveis de controle e revisão judicial (GÓRRIZ ROYO, 2004). Por conseguinte, o respeito a essa regra se vincula ao direito ao devido processo legal, com a aplicação de todas as

4 Em crítica a esse posicionamento do Tribunal Constitucional espanhol, argumenta-se que a regra da preferência da jurisdição penal também encontra respaldo na Constituição, de modo que "não seria uma mera garantia complementar do princípio 'ne bis in idem', mas sim a principal e única garantia deste ou o prius lógico para assegurar que ninguém possa ser castigado duplamente por um mesmo ilícito nos casos em que este possa ser constitutivo de infração administrativa e delito"; além disso, "a referida regra goza de substantividade própria - reconhecida pela jurisprudência constitucional -, de forma que pode operar de maneira autônoma e prévia ao princípio". Logo, "o conflito que o T. C. aprecia entre a regra de preferência da jurisdição penal e o ne bis in idem é aparente, pois deriva de um entendimento desenfocado daquela regra ao não assumir-se que a mesma deveria ter operado nesse caso como pressuposto da aplicação do ne bis in idem" (GÓRRIZ ROYO, 2004, p. 213-214, nota 48). 
suas garantias. Dado que, na prática, ao processo administrativo não se estendem todas as garantias processuais penais, o cidadão teria direito ao devido processo legal antes mesmo de ser processado na esfera administrativa. Logo, quando se concede - ainda que excepcionalmente, como na hipótese em questão - prioridade à condenação no âmbito administrativo, relativiza-se a própria garantia ao devido processo legal. E como entre as garantias do processo penal está a vedação ao bis in idem - havendo identidade de fato, sujeito e fundamento -, em última instância, a regra de preferência da jurisdição penal atua como autêntica "cláusula de salvaguarda" (GÓRRIZ ROYO, 2000, p. 275) da efetividade daquele princípio.

Com efeito, o reconhecimento da prioridade ou preferência da jurisdição penal na apreciação de uma conduta que possa constituir igualmente infração administrativa não pode sofrer uma relativização fundada em uma simples questão cronológica - a saber, a conclusão anterior do procedimento administrativo -, posto que está vinculado a aspectos teleológicos relacionados aos fins garantistas inerentes ao devido processo legal. Nessa perspectiva, a proibição constitucional ao bis in idem não significa simplesmente optar por uma das esferas sancionadoras - administrativa ou penal - e admitir que essa opção se baseie em um mero critério cronológico ${ }^{5}$, de acordo com o qual o exercício do ius puniendi estatal por parte de qualquer dos ramos do direito sancionador impediria nova apreciação do mesmo fato. Se assim fosse, sempre que uma conduta delitiva fosse sancionada na esfera administrativa com sanções menos gravosas - o que normalmente costuma ocorrer, uma vez que a diferença entre delitos e infrações administrativas é quantitativa, e não qualitativa -, a conclusão prévia do

Como sustenta, por exemplo, Nieto (2002, p. 423-424): "a regra do non bis in idem impede a dupla sanção pelos mesmos fatos, mas intrinsecamente nada diz sobre prioridades. Desse modo, poderia entrar aqui em jogo o critério cronológico: a primeira sentença condenatória veta a segunda [...] qualquer que seja sua procedência, a tal ponto que uma simples resolução administrativa impede por si só as atuações penais posteriores". 
procedimento administrativo obstaculizaria a aplicação da sanção penal correspondente 6 . Admitindo-se o princípio da unidade do ordenamento jurídico sancionador, o fundamento da regra de preferência da jurisdição penal sobre a potestade administrativa deveria radicar em critérios materiais, representados pelo princípio constitucional do devido processo legal, cercado de garantias, e, segundo um setor da doutrina, pelo critério quantitativo que orienta a diferenciação entre sanções penais e administrativas (PÉREZ MANZANO, 2005, p. 60-64). Esta última opinião, porém, não pode ser acatada integralmente.

De fato, embora se reconheça que a distinção entre ilícitos penais e administrativos é apenas quantitativa, não é possível deduzir dessa premissa o fundamento material da regra de preferência da jurisdição penal; tampouco a vedação ao bis in idem. Como acertadamente se observa, o non bis in idem "é um princípio valorativamente neutro" (GÓRRIZ ROYO, 2004, p. 222, nota 63, e p. 223), que se limita a proibir a duplicidade de sanções pela prática de uma mesma conduta e nada diz acerca de qual face do ius puniendi estatal deve prevalecer. A prioridade da apreciação da conduta pela jurisdição penal, em detrimento da potestade administrativa, não pode ser extraída do princípio do non bis in idem, e sim do princípio constitucional do devido processo legal. Tampouco é possível deduzir do princípio a maior gravidade dos ilícitos penais. Se assim fosse, quando o ordenamento jurídico-penal e o administrativo sancionassem hipóteses fáticas idênticas, sem que se pudesse vislumbrar qualquer elemento que indicasse a maior gravidade do injusto penal, não haveria obstáculo algum à admissibilidade eventual do bis in idem. $\mathrm{E}$ isso é precisamente o que ocorre no âmbito da legislação administrativa brasileira orientada à proteção ambiental, que simplesmente repete, na maioria das vezes, os ilícitos penais ambientais tipificados anteriormente pela Lei 9.605/98. A ausência de um plus que indique a maior gravidade do ilícito penal pode atuar como pretexto para a admissibilidade do bis in idem, como de fato ocorre.

Adverte que o entendimento consagrado na STC 177/1999 abre perigosa brecha para que se burle a jurisdição penal em casos de correspondência total ou parcial do substrato fático de um delito com alguma infração administrativa, por exemplo, Górriz Royo (2004, p.221). 
Assinala-se que a existência de uma relação de consunção em sentido material entre a infração administração e o delito, segundo a qual este absorve o conteúdo de injusto daquela, seria o critério material que explicaria "a supremacia da ordem penal sobre a administrativa e a regra da subsidiariedade da atuação dos órgãos da Administração em matéria sancionadora" (PÉREZ MANZANO, 2005, p. 62). Esse argumento poderia fazer sentido quando se constata uma maior gravidade do injusto penal em relação ao administrativo, aferida com a introdução típica de elementos que qualificam o ilícito penal. A própria autora admite que "essa maior gravidade das infrações penais procede de que normalmente contém os elementos da infração administrativa e acrescenta algum elemento de desvalor específico" (PÉREZ MANZANO, 2005, p. 62), o que termina por ensejar uma relação de subsidiariedade tácita entre ilícito penal e administrativo - ou de consunção, como prefere denominar. Todavia, quando se parte da identidade entre o conteúdo do ilícito penal e da correspondente infração administrativa, como ocorre na legislação ambiental brasileira, já não é mais possível concluir pela maior gravidade daquele. Logo, o substrato material apontado pela referida autora não lograria explicar satisfatoriamente a prioridade da jurisdição penal. Porém, é possível vislumbrar a maior gravidade das consequências jurídico-penais em relação às sanções administrativas. $\mathrm{E}$ isso porque, mesmo quando cominada uma multa penal inferior à administrativa, ela se reveste de um maior efeito estigmatizante.

É certo que "a concepção de uma infração administrativa absolutamente idêntica a uma infração penal passa uma imagem de legislador pouco racional", seja porque com esse proceder infringe o princípio da intervenção mínima "posto que se a sanção administrativa é suficiente carece de sentido a intervenção penal", seja porque "uma das sanções não guarda proporcionalidade com o conteúdo de injusto da infração (já que a mesma conduta não pode resultar proporcionadamente sancionada com duas sanções de distinta natureza e gravidade)" (PÉREZ MANZANO, 2005, p. 62). Entretanto, é justamente diante de legisladores pouco racionais que recobra sentido a busca de um fundamento material capaz de, por um lado, evitar - pelo menos sob a 
perspectiva processual - o bis in idem e de, por outro lado, explicar a preferência pela jurisdição penal. $\mathrm{E}$ o fundamento material desta última poderia radicar no princípio constitucional do devido processo legal (art. $5^{\circ}$, LIV, CF), do qual se pode extrair a regra da subordinação da atuação administrativa à jurisdição penal.

O certo é que o princípio non bis in idem e a regra de preferência da jurisdição penal em detrimento da administrativa apresentam fundamentos materiais próprios e, de momento, interessa elucidar se é possível extraí-los de algum dos princípios penais de garantia reconhecidos - expressa ou tacitamente - no texto constitucional brasileiro. O princípio non bis in idem veda a duplicidade de sanções (perspectiva material) e de processos (perspectiva processual) quando constatada a referida tríplice identidade (sujeito, fato, fundamento). Mas não indica qual a sanção aplicável ou qual procedimento deve ser iniciado primeiramente. Essa neutralidade valorativa impede encontrar, na própria vedação ao bis in idem, o fundamento material da regra de preferência da jurisdição penal. O fundamento dessa prioridade pode, porém, residir no princípio constitucional do devido processo penal, pautado pelo respeito ao contraditório e à ampla defesa, passíveis de relativização na esfera administrativa.

Além disso, é preciso observar que, se o principio da intervenção mínima corrobora o caráter subsidiário do direito penal, isso não significa preferência concreta pela potestade sancionadora da Administração. Se, do ponto de vista abstrato, a intervenção jurídico-penal só deve ocorrer com o escopo de tutelar bens jurídicos importantes - como é o caso do meio ambiente (art. 225, $\S 3^{\circ}, \mathrm{CF}$ ) - e em face de agressões significativas, sob a perspectiva concreta, a partir do momento em que o legislador penal opta pela tipificação de uma conduta como delitiva, isso significa que já houve uma valoração prévia que concluiu pela necessidade da intervenção penal. A prévia intervenção administrativa não se revelava suficiente e adequada para oferecer a proteção necessária ao bem jurídico lesado ou ameaçado de lesão. Nesse processo de valoração das condutas passíveis de tipificação penal, é de todo conveniente que o legislador penal determine com precisão 
o núcleo da proibição e, na configuração do tipo penal, introduza elementos que indiquem a maior gravidade do ilícito penal, a fim de fundamentar a maior gravidade da consequência jurídica (de natureza penal) abstratamente prevista ${ }^{7}$. Se não é possível introduzir na descrição típica elementos capazes de indicar a maior gravidade (quantitativa) da intervenção sancionadora penal, isso pode indicar que a conduta previamente configurada como simples infração administrativa deve ser penalmente tipificada, independentemente de apresentar qualquer conteúdo de desvalor adicional. Se assim for, é conveniente que sua transformação em delito seja acompanhada pela correspondente revogação da infração administrativa, a fim de evitar duplicidade de normas com idêntico conteúdo. Todavia, se esse proceder não for adotado quando da criação de novas figuras delitivas, poderão ocorrer - tal como se constata na legislação ambiental brasileira - diversas hipóteses nas quais uma mesma conduta recebe, simultaneamente, sanções penais e administrativas, dado que é descrita da mesma forma tanto pela legislação penal ambiental como pela normativa administrativa sancionadora.

Diante desse equivocado panorama legislativo, faz-se necessário solucionar os problemas materiais e processuais dele derivados. Assim, sob a perspectiva processual, é preciso evitar a duplicidade de processos - penal e administrativo -, especialmente a fim de afastar decisões contraditórias. Nessa perspectiva, a regra de preferência da jurisdição penal assegura efetividade à vedação do bis in idem em seara processual. Deve-se conceder preferência à aplicação da normativa penal sempre que uma mesma conduta for sancionada pelos dois ramos do ordenamento jurídico (penal e administrativo). Esse proceder não implica em infração à intervenção mínima - princípio que deve pautar a atuação legislativa em matéria penal - e tampouco contradiz o caráter subsidiário do direito penal. $\mathrm{E}$ isso porque, quando se trata da concorrência de normas penais e administrativas, a perspectiva da

Sobre a matéria, Carvalho (2011, p. 299-335). 
subsidiariedade se inverte e assume outros contornos, já que agora o que se trata é de determinar qual a normativa aplicável. $\mathrm{E}$, havendo concurso de normas penais e administrativas, "rege o critério da subsidiariedade da norma administrativa, de forma que esta só entrará em jogo quando não tenha sido aplicada - com resultado condenatório - a lei penal" (NIETO, 2002, p. 444).

Pois bem, o importante será examinar até que ponto essa prioridade da normativa penal significa exclusividade ou se é possível que a conclusão do processo administrativo figure apenas como pressuposto indispensável (questão prejudicial) à posterior intervenção penal; ou, por fim, se é admissível a instauração de um procedimento administrativo após a conclusão do correspondente processo penal, em função do conteúdo da sentença prolatada.

No que concerne ao fundamento material do princípio non bis in idem, cabe frisar que, diversamente do disposto na Constituição espanhola (art. 25.1, CE), o texto constitucional brasileiro configura o princípio da legalidade como princípio da legalidade dos delitos e das

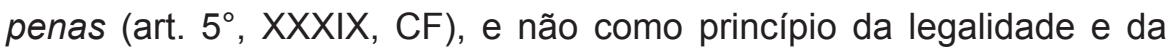
tipicidade das infrações e sanções em sentido amplo ${ }^{8}$. Por essa razão, parece inapropriado vincular o respeito ao non bis in idem ao princípio da legalidade, como fazem a jurisprudência constitucional e a doutrina espanholas. No Brasil, porém, a busca por um supedâneo ao princípio non bis in idem em seu aspecto material poderia encontrar no princípio da proporcionalidade - implicitamente consagrado na Constituição Federal - sólido fundamento. Nessa perspectiva, faz-se oportuno invocar a mudança de orientação do Tribunal Constitucional espanhol, representada pela sentença $n^{\circ} 2$, de 16 de janeiro de 2003 .

Com efeito, a STC 2/2003 revisa o criticado entendimento anterior (STC 177/1999) e tece importantes considerações a respeito do

8 De acordo com o artigo 25.1 da Constituição espanhola de 1978, "ninguém pode ser condenado ou sancionado por ações ou omissões que no momento de sua produção não constituam delito, contravenção ou infração administrativa, segundo a legislação vigente naquele momento". 
fundamento material e processual do non bis in idem. Algumas dessas considerações podem ser especialmente úteis quando se pretende perquirir qual o papel desempenhado por esse princípio, no Brasil, em seara ambiental. Pois bem, o Tribunal Constitucional espanhol reconhece que o princípio non bis in idem constitui um direito fundamental do cidadão a não ser sancionado duplamente (desde que constatado o pressuposto representado pela tríplice identidade), vinculando-o como garantia material ao princípio da tipicidade e da legalidade das infrações (art.25.1, CE). Todavia, a STC 2/2003 inova ao invocar, como fundamento material à proibição ao bis in idem, o princípio da proporcionalidade e, ao fazêlo, afirma que a finalidade dessa garantia é "evitar uma reação punitiva desproporcional", porque "esse excesso punitivo rompe a garantia do cidadão de previsibilidade das sanções, pois a soma da pluralidade de sanções cria uma sanção alheia ao juízo de proporcionalidade realizado pelo legislador e materializa a imposição de uma sanção não prevista legalmente". Desse modo, o Tribunal Constitucional espanhol conecta materialmente o princípio da proporcionalidade ao princípio da legalidade, em sua vertente da segurança jurídica, pois "uma duplareação ou uma reação desproporcionada do ordenamento sancionador materializa uma sanção não prevista legalmente e, por isso, atenta contra a necessária segurança jurídica" (GÓRRIZ ROYO, 2004, p. 243).

Do ponto de vista processual, a STC 2/2003 relaciona o princípio do non bis in idem ao direito à obtenção de uma tutela judicial efetiva, previsto no artigo 24 da Constituição espanhola ${ }^{9}$. Nesse sentido, uma infração ao bis in idem em sua vertente processual pode ser compensada com a absorção da sanção administrativa imposta pela sanção penal. No caso em apreço, a multa aplicada em seara administrativa foi computada

9 Dispõe o artigo 24 da Constituição espanhola que "1. Todas as pessoas têm direito a obter a tutela efetiva dos Juízes e Tribunais no exercício de seus direitos e interesses legítimos, sem que, em nenhum caso, possa produzir-se a falta de defesa. 2. Igualmente, todos têm direito ao Juiz ordinário predeterminado pela lei, à defesa e à assistência por parte de advogado, a ser informado da acusação formulada contra eles, a um processo público sem dilações indevidas e com todas as garantias, a utilizar os meios de prova pertinentes para sua defesa, a não declarar contra si mesmos, a não confessar sua culpa e à presunção de inocência". 
na sanção penal pecuniária aplicada. O desconto feito pela sentença de primeira instância foi referendado pelo Tribunal Constitucional espanhol, que vislumbrou na referida compensação uma forma de evitar o excesso punitivo proibido pelo bis in idem. Assim, embora formalmente houvesse uma duplicidade sancionadora, o desconto efetuado da multa administrativa na multa penal imposta afasta, em termos materiais, a existência de uma reação sancionadora desproporcional ${ }^{10}$. Por outra parte, o Tribunal Constitucional espanhol, na STC 2/2003, realizou um detido exame do significado e do alcance da regra de preferência da jurisdição penal, qualificando-a como "um instrumento preventivotendente a preservar os direitos a não ser submetido a um duplo procedimento sancionador - administrativo e penal - e a não ser sancionado em mais de uma ocasião pelos mesmos fatos". O fundamento da referida regra se encontraria no princípio constitucional da separação de poderes e, havendo idêntico pressuposto fático previsto simultaneamente em uma norma penal e em outra administrativa, conclui pela prevalência da aplicação daquela em detrimento desta, pois o único poder público com competência para exercer a potestade sancionadora seria a jurisdição penal.

Porém, conclui a STC 2/2003 que não há infração ao direito fundamental de não ser sancionado duplamente quando, paralelamente ao processo penal, houver a instauração ou a conclusão de um procedimento administrativo. Um procedimento administrativo sancionador não importaria em reiteração sancionadora (bis), seja do ponto de vista material, seja sob a perspectiva processual. Não é possível equiparar o procedimento administrativo ao processo penal. E a impossibilidade de equiparação - que vulneraria a vedação ao bis in idem -, segundo entendimento da STC 2/2003, ocorre porque o procedimento administrativo oferece garantias inferiores ao cidadão

10 Em sentido contrário, argumenta-se que "nem sequer quando materialmente se realiza a compensação, o certo é que se causa" - ao cidadão - "uma dupla vexação ao submetê-lo duas vezes a um procedimento pelos mesmos fatos e com igual fundamento". (GÓRRIZ ROYO, 2004, p. 255). 
e não se efetiva respeitando as necessárias garantias inerentes a um processo penal.

Posto isto, é necessário examinar se é possível extrair um fundamento material ao princípio non bis in idem no ordenamento jurídico brasileiro, e se tal princípio poderia radicar no princípio da proporcionalidade. Além disso, assumindo que a vertente material da vedação ao bis in idem inspira e condiciona sua perspectiva processual, caberá analisar quando uma determinada hipótese fática poderá ser duplamente apreciada (nas esferas administrativa e penal) e, eventualmente, duplamente sancionada.

\section{A duplicidade sancionadora em matéria ambiental no Brasil}

A legislação penal brasileira coincide com a normativa administrativa sancionadora em matéria ambiental no que concerne à configuração de inúmeras infrações. E a constatada identidade de hipóteses fáticas acarreta uma superposição normativa altamente nociva e criticável. O princípio non bis in idem poderia ser a única forma de afastar a duplicidade sancionadora em relação às pessoas físicas. Subscreve-se, aqui, o entendimento segundo o qual:

a duplicidade normativa sancionadora é conseqüência de uma incoerência ou falta de coordenação da legislação que agrava sem fundamento a posição do autor. E é cabalmente a regra do non bis a que permite bloquear a superposição de sanções considerada injusta, operando em definitivo como uma válvula de segurança ou mecanismo corretor de deficiências normativas. (NIETO, 2002, p. 442)

Pois bem, quando se tomam como exemplo os delitos contra a fauna tipificados na Seção I (Dos crimes contra a fauna), do Capítulo V (Dos crimes contra o meio ambiente), da Lei 9.605/98, atesta-se que todos se encontram previstos como infrações administrativas no âmbito do Decreto 6.514/08. Com efeito, os crimes constantes nos artigos 29, caput, $\S 1^{\circ}$, I, II, III; 30; 31; 32; 33, caput, e parágrafo único, I, II e III; 34, 
caput e parágrafo único, I, II e III; 35, I e II, da Lei 9.605/98, correspondem, respectivamente, às infrações previstas nos artigos 24 , caput, $\S 3^{\circ}$, I, II e III; 26; 25; 29; 62, VIII, 34, caput, e 39, caput, e parágrafo único, II; e 36, do Decreto 6.514/08. O legislador brasileiro opta por conferir a ilícitos penais e administrativos idêntico conteúdo material. Isso significa que sequer do ponto de vista quantitativo é possível extrair a maior gravidade do injusto penal em relação ao administrativo. A diferença quantitativa entre ilícitos penais e administrativos se limita à maior gravidade das consequências penais.

Diante desse quadro legislativo, quando um mesmo sujeito realiza uma conduta tipificada, simultaneamente, como ilícito penal e administrativo estará sujeito às penas e às sanções administrativas cominadas. Isto é, ainda que constatada a tríplice identidade que funciona como pressuposto indispensável ao reconhecimento do bis in idem, admite-se a duplicidade sancionadora. Há, no Brasil, uma visão distorcida do princípio non bis in idem, ademais de um emprego meramente simbólico e negativo do direito penal para a sanção de determinadas condutas merecedoras exclusivamente de uma sanção administrativa (PRADO, 2012, p. 92-98).

No que concerne à perspectiva processual do non bis in idem, iniciado o procedimento administrativo orientado à apuração de uma infração ambiental, este deve ser paralisado até a conclusão do processo penal, a fim de evitar decisões contraditórias. Após o término do processo penal, a continuidade do procedimento administrativo ou sua instauração só será admitida quando o sujeito não tiver sido absolvido em razão da inexistência material do fato. Em realidade, ainda que se subordine a atividade sancionadora da Administração à atuação judicial e se consagre a prevalência da jurisdição penal sobre a administrativa em caso de conflito, a aplicação de uma sanção penal não impede que posteriormente se fixe - ao mesmo sujeito e em virtude da mesma conduta - uma sanção administrativa. Ademais, ainda que a prioridade da jurisdição penal sobre a administrativa se harmonize com o texto constitucional de 1988 - que reconhece maiores garantias individuais em seara processual penal e consagra os princípios da divisão de poderes 
e da legalidade aplicados à Administração Pública (art. 37, caput, CF) -, tem-se uma clara relativização do princípio da unidade do ordenamento jurídico no Brasil, dado que se parte do princípio da independência das esferas penal e administrativa e, consequentemente, não se vislumbra ofensa ao non bis in idem na manifestação plural do ius puniendi estatal.

Como forma de compensar a duplicidade sancionadora - na linha da STC n. 2/2003 antes examinada - e com o objetivo de mitigar a violação à regra da prevalência da jurisdição penal, admite-se que se efetue a compensação, na sanção penal imposta, daquela aplicada no âmbito administrativo. Assim, caso o procedimento administrativo siga seu curso e termine antes da instauração do correspondente processo penal, em virtude da prática da mesma conduta e contra o mesmo sujeito, computa-se na sanção penal ulterior a sanção administrativa primeiramente imposta. $\mathrm{Na}$ trilha do entendimento do Tribunal Constitucional espanhol em sua STC 2/2003, vislumbra-se, no referido cômputo, uma forma de evitar o excesso punitivo proibido pelo bis in idem. Logo, embora do ponto de vista formal seja possível constatar uma duplicidade sancionadora, o desconto, por exemplo, da multa administrativa ambiental na multa penal aplicada afastaria, em termos materiais, a existência de uma reação sancionadora desproporcional. Assim, considera-se que não haverá excesso punitivo em razão da inexistência de reiteração sancionadora, ou seja, ter-se-ia, em realidade, uma única sanção, que abarcaria todo o desvalor da conduta realizada. Além disso, é possível, no Brasil, a revisão das atuações administrativas precedentes e, inclusive, a anulação das sanções administrativas impostas (PRADO, 2012, p. 98).

No Brasil, o princípio non bis in idem tem seu âmbito de aplicação limitado à vedação da superposição de sanções ou ao concurso simultâneo de processos - presente a tríplice identidade - na esfera de um mesmo ramo do ordenamento jurídico. Enquanto a proibição da imposição de dupla sanção penal ao autor, coautor ou partícipe de uma determinada conduta delitiva é prontamente rechaçada pela doutrina e jurisprudência pátrias - posto que o artigo 15, caput, da Lei 9.605/98, veda que se aprecie, como agravante, circunstância que constitua ou 
qualifique o crime -, o mesmo não se pode dizer acerca da imposição simultânea de sanção penal e administrativa. A reiteração sancionadora em matéria ambiental é plenamente admitida pela doutrina e pela jurisprudência, uma vez que a própria Constituição Federal, em seu artigo $225, \S 3^{\circ}$, dispõe que "as condutas e atividades consideradas lesivas ao meio ambiente sujeitarão os infratores, pessoas físicas ou jurídicas, a sanções penais e administrativas, independentemente da obrigação de reparar os danos causados" (grifou-se). Nessa perspectiva, a Lei 9.605/98, em seu artigo $3^{\circ}$, estipula que "as pessoas jurídicas serão responsabilizadas administrativa, civil e penalmente conforme o disposto nesta Lei [...]" (grifou-se). Logo, é possível afirmar que a maioria da doutrina brasileira, bem como a jurisprudência consolidada, respaldada pelos dispositivos citados, não vislumbra qualquer violação ao princípio non bis in idem na imposição sucessiva de uma sanção penal e de penalidade administrativa (sobretudo se efetuado o referido cômputo). De outra parte, a prevalência da jurisdição penal - regra às vezes relativizada - operaria como salvaguarda do non bis in idem em seu aspecto processual.

Todavia, a regra da prevalência da jurisdição penal em relação à atuação da Administração só atua como cláusula de salvaguarda do princípio non bis in idem quando o pronunciamento jurisdicional anterior produz determinados efeitos. Do contrário, como acontece no Brasil, trata-se de uma questão meramente cronológica, já que apenas quando a sentença penal absolutória reconhece a inexistência material do fato haverá autêntico obstáculo à intervenção administrativa posterior. Se não for assim, nada impede que o fato seja apreciado também na esfera extrapenal e que seu autor (pessoa física e/ou jurídica) seja também condenado a uma sanção administrativa pela prática da conduta descrita como infração ambiental. Na Espanha, porém, um dos efeitos negativo - do princípio non bis in idem consiste, segundo a sistemática geral elaborada pela doutrina penal e pela jurisprudência (NIETO, 2002), em impedir a superveniência de uma resolução posterior. Ou seja, se a decisão penal se pronuncia sobre o mérito, tal sentença - condenatória ou absolutória - representa um obstáculo a ulteriores pronunciamentos. 
Por conseguinte, o non bis in idem é concebido em sentido amplo, impedindo a duplicidade de processos sancionadores, desde que presente a tríplice identidade. Quando, excepcionalmente, o mesmo fato for objeto de apreciação pela instância administrativa, o princípio non bis in idem acarretará como efeito - positivo - a obrigação de levar necessariamente em consideração o conteúdo da decisão penal.

No Brasil, conforme se extrai da doutrina e da jurisprudência, a independência das instâncias penal e administrativa significa que o non bis in idem impede exclusivamente a imposição de dupla sanção penal presente a tríplice identidade. O princípio non bis in idem não é concebido em sentido amplo. A intervenção sancionadora da Administração Ambiental só será obstaculizada quando reconhecida a inexistência material do fato. Uma sentença penal condenatória não vedará a posterior instauração de um processo administrativo e a eventual aplicação de uma sanção nessa esfera. Mitiga-se a reiteração sancionadora com o cômputo da sanção penal anteriormente imposta. Eventualmente, se o procedimento administrativo ambiental for iniciado e concluído antes da instauração do processo penal, poderá o juiz levar em consideração a penalidade administrativa aplicada e, quando cabível, efetuar o referido cômputo. Este evitaria, em todo caso, uma violação "substancial" ao bis in idem. Quando a regra de preferência da jurisdição penal é infringida, o juiz penal não se vincula ao pronunciamento veiculado no âmbito administrativo. Em resumo, o non bis in idem, tal como concebido pelo ordenamento jurídico brasileiro, não proíbe a duplicidade de processos e sanções pela prática de uma conduta prevista simultaneamente como delito e infração administrativa.

Posto isso, faz-se necessário indagar se essa concepção do princípio non bis in idem realmente se harmoniza com o disposto em tratados e convenções internacionais, os quais o elencam como um direito fundamental. Sob a perspectiva da Convenção Americana Sobre Direitos Humanos (Pacto de San José da Costa Rica), de 1969, aprovada no Brasil pelo Decreto legislativo n. 27, de 25 de setembro de 1992, e promulgada pelo Decreto n. 678, de 6 de novembro de 1992, o non bis in idem é tido como uma garantia judicial no artigo $8^{\circ}$, item 12 , 
segundo o qual "o acusado absolvido por sentença passada em julgado não poderá ser submetido a novo processo pelos mesmos fatos". Essa Convenção consagra uma noção ampla do princípio. Conforme o disposto no $\S 2^{\circ}$ do artigo $5^{\circ}$ da CF, "os direitos e garantias expressos nesta Constituição não excluem outros decorrentes do regime e dos princípios por ela adotados, ou dos tratados internacionais em que a República Federativa do Brasil seja parte". Nesse sentido, a Emenda Constitucional n. 45/2004 acrescentou o $\S 3^{\circ}$, a qual dispõe que "os tratados e convenções internacionais sobre direitos humanos que forem aprovados, em cada Casa do Congresso nacional, em dois turnos, por três quintos dos votos dos respectivos membros, serão equivalentes às emendas constitucionais". A referida convenção internacional procura reafirmar, no âmbito dos países membros da OEA, um regime de liberdade pessoal e justiça social, fundado no respeito aos direitos humanos fundamentais, com independência do lugar de residência (GOMES, 2009).

Predomina no Supremo Tribunal Federal brasileiro uma corrente liderada pelo ministro Gilmar Mendes, segundo a qual os acordos e tratados internacionais que versem sobre direitos humanos "têm status acima das leis ordinárias, porém abaixo dos dispositivos contidos na própria Constituição, salvo se ratificados em votação semelhante às das propostas de emendas constitucionais" (RE 466.343-SP, de 3 de dezembro de 2008). A Convenção Americana Sobre Direitos Humanos não foi aprovada pelo quórum qualificado exigido pelo $\S 3^{\circ}$ do artigo $5^{\circ}$ da Constituição Federal para que logre status de Emenda Constitucional. Todavia, tem-se reconhecido "o caráter especial desses diplomas internacionais sobre direitos humanos", o que lhes confere "lugar específico no ordenamento jurídico, estando abaixo da Constituição, porém acima da legislação interna" (RE 466.343-SP, de 03 de dezembro de 2008, Rel. Min. Gilmar Mendes). Em virtude desse entendimento, a prisão civil do depositário infiel, embora prevista no artigo $5^{\circ}, \mathrm{LXVII}, \mathrm{CF}$, tem sido rechaçada majoritariamente por violar o Pacto Internacional dos Direitos Civis e Políticos (art.11) e a Convenção Americana sobre Direitos Humanos $\left(\operatorname{art.} 7^{\circ}, 7\right)$, ratificados pelo Brasil em 1992. Nessa 
perspectiva, outorgando-se ao princípio non bis in idem o caráter de direito fundamental, tal como previsto pela Convenção Americana sobre Direitos Humanos (art. $\left.8^{\circ}, 12\right)$, a imposição de sucessivas sanções penais e administrativas - constatada a tríplice identidade - encontraria sério obstáculo.

\section{Conclusão}

Ante o exposto, é possível concluir que o legislador brasileiro optou por conferir à quase totalidade dos ilícitos administrativos o mesmo conteúdo das condutas delitivas constantes da Lei 9.605/98. Esse proceder acarreta vários inconvenientes. De fato, essa superposição normativa demonstra, de início, que ao direito penal do ambiente se confere um papel de reforço da normativa administrativa ambiental. A ausência de elementos qualificadores, por outro lado, demonstra que os ilícitos penais não apresentam um maior conteúdo de injusto ou um conteúdo de injusto específico em relação aos injustos administrativos. A maior gravidade daqueles, portanto, residiria apenas na maior severidade das sanções cominadas (CARVALHO, 2011, p. 299-335).

O princípio non bis in idem, como bem se adverte, veda que "um mesmo fato seja duplamente sancionado, não que seja duplamente tipificado administrativa e penalmente" (DEL REY GUANTER, 1990, pp. 125-126), ou seja, "seu âmbito próprio é a sanção, não a infração" (NIETO, 2002, p. 404). E, em razão de sua neutralidade valorativa, não indica qual das normas existentes deve ser aplicada. Portanto, a previsão simultânea - em abstrato - de uma mesma conduta que lese ou exponha a perigo de lesão os recursos naturais como infração administrativa e delito não entra em conflito direto com o conteúdo do princípio non bis in idem. Este, porém, quando concebido em sentido amplo - noção que inspira alguns tratados e convenções internacionais em matéria de direitos fundamentais - proíbe a duplicidade sancionadora. Logo, sob a perspectiva material, o princípio em apreço rechaça a dupla aplicação de sanções penais e administrativas. Contudo, essa superposição só será 
aventada em concreto quando o próprio legislador, de forma equivocada, configurar de forma idêntica delitos e infrações administrativas.

Em resumo, se o verdadeiro problema "é de política legislativa, o que o Estado deve se perguntar, quando decide reprimir um fato, é se convém tipificá-lo como delito ou como infração administrativa, já que tem em sua mão ambas as possibilidades" e, "salvo exceções, é melhor não utilizá-las simultaneamente" (NIETO, 2002, p. 405). O curioso é que, em algumas situações, emprega-se na redação dada à infração administrativa melhor técnica legislativa - como ocorre no artigo 26, do Decreto 6.514/08, que suprime o incorreto "exportar para o exterior" do artigo 30 da Lei 9.605/98 - ou se verifica uma melhor delimitação da conduta tipificada - como acontece com o artigo 25, do Decreto 6.514/08, se comparada com o delito do artigo 31 da Lei dos Crimes Ambientais.

É certo, por um lado, que a própria Lei Ambiental não afasta a possibilidade de aplicação concomitante de sanções penais e administrativas, dado que a Constituição Federal (art.225, §3 ${ }^{\circ}$ ) dispõe que as pessoas físicas e jurídicas responderão administrativa, civil e penalmente pelas condutas e atividades lesivas ao meio ambiente. Porém, quando se concebe o ordenamento jurídico como uma unidade, tem-se que a reiteração do ius puniendi implica em inequívoco bis in idem. Com efeito, a pluralidade de sanções - penais e administrativas - aplicadas em virtude da prática de uma conduta tipificada simultaneamente como delito e infração administrativa é uma infração ao non bis in idem em sua vertente material.

Em síntese, diante do panorama legislativo brasileiro, é possível extrair as seguintes conclusões parciais: a) o legislador opta por configurar a maioria dos ilícitos administrativos com o mesmo conteúdo conferido aos ilícitos penais ambientais, raramente introduzindo elementos qualificadores. Quando tais elementos são introduzidos na configuração dos tipos penais, tem-se um maior conteúdo de injusto ou um conteúdo de injusto específico que permitem vislumbrar uma diversidade de fundamento em relação ao ilícito administrativo. E, em 
razão dessa diversidade de fundamento, afastar-se-ia o bis in idem; b) o recurso a uma técnica legislativa equivocada - ou, o que é o mesmo, a ausência de uma maior reflexão no momento de configurar os ilícitos penais ambientais - motiva, inclusive, importantes e pertinentes críticas acerca da conveniência e necessidade de intervenção do direito penal na tutela do bem jurídico ambiente. Em todo caso, a infração de princípios penais pelo legislador brasileiro ao estruturar os ilícitos penais ambientais - como o de taxatividade e de intervenção mínima - não deve ser um obstáculo à defesa da pertinência da intervenção jurídico-penal nessa matéria; c) o princípio non bis in idem, que não apresenta fundamento constitucional explícito, não impede a pluralidade de tipos - penais e administrativos -, e sim a imposição concreta de várias sanções, presente a tríplice identidade; d) o princípio non bis in idem é valorativamente neutro, não indicando, na hipótese de concurso de normas, qual deve prevalecer; e) o princípio non bis in idem poderia funcionar como uma cláusula corretiva, evitando que a superposição normativa em abstrato acarretasse uma superposição de sanções concretas. Ou seja, a vertente material do non bis in idem poderia corrigir a técnica legislativa defeituosa, a saber, a configuração idêntica de ilícitos administrativos e penais; f) para efetuar essa correção, seria necessário, de início, um critério doutrinário que permitisse a opção concreta por uma das normas sancionadoras, em detrimento da outra. O problema da pluralidade das tipificações normativas idênticas poderia ser solucionado através dos princípios invocados para a resolução do conflito aparente de normas penais, mais precisamente pelo princípio da subsidiariedade; g) no Brasil, a vedação à duplicidade de processos se limita ao âmbito processual penal. Todavia, o respeito à coisa julgada penal e a exigência de segurança jurídica, incompatível com a presença de decisões contraditórias, reforçam a necessidade de se conferir prevalência à jurisdição penal.

Excetuada a hipótese de inexistência material dos fatos, seria possível que estes fossem apreciados também no âmbito administrativo sancionador. Havendo sentença penal condenatória, o cômputo da sanção penal aplicada - quando de caráter pecuniário, por exemplo - 
na sanção administrativa eventualmente imposta seria uma forma de afastar a infração ao bis in idem em seu aspecto material. Não sendo possível o referido cômputo, a imposição de uma sanção administrativa não é tida, no Brasil, como violação ao non bis in idem. Se absolutória a sentença penal, desde que não se reconheça a inexistência do fato, será possível a atuação posterior da potestade administrativa. É possível argumentar que, quando a legislação permite a abertura ou a continuidade de um processo administrativo após a conclusão do processo penal, não há infração ao non bis in idem em seu aspecto processual. Nesses casos, haveria um único procedimento sancionador, embora dividido em duas fases: uma perante a jurisdição penal e outra perante a Administração Ambiental (PÉREZ MANZANO, 2005). Há um único processo sancionador, de modo que a apreciação feita a posteriori pela Administração deve considerar a análise que a jurisdição penal faz dos fatos.

A tão criticada inflação normativa em matéria ambiental se consubstanciou, no ordenamento jurídico brasileiro, na elaboração de normas penais e administrativas com idêntico conteúdo de injusto. Desse modo, a proteção do ambiente como bem jurídico pelo direito administrativo e pelo direito penal conduziu a uma superposição normativa "fruto de uma política legislativa preocupada tão-somente em não deixar lacunas de punição e carente de critérios claros de delimitação" (PÉREZ MANZANO, 2005) entre ilícitos penais e administrativos.

Diante desse equivocado panorama legal, cabe questionar se a duplicidade sancionadora implicaria em bis in idem. E, além disso, se esse bis seria tolerado pelo ordenamento jurídico brasileiro. Pois bem, a resposta a esse questionamento inicial deve ser negativa. O princípio non bis in idem não proíbe a previsão abstrata de infrações penais com idêntico conteúdo de injusto. Veda, isso sim, a imposição cumulativa de sanções penais e administrativas quando se confere ao citado princípio um sentido amplo. Entretanto, conforme se depreende do exame da legislação e da doutrina nacionais, só há bis quando se constata cumulação entre sanções penais. Sequer se aventa a possibilidade de concurso aparente de normas sancionadoras; há um concurso 
de infrações (penal e administrativa). Agora, cumpre questionar se o princípio non bis in idem poderia funcionar como um instrumento capaz de mitigar os nefastos efeitos práticos que essa superposição normativa abstrata pode acarretar.

Nessa perspectiva, apesar de não constar na CF e não se conectar, no Brasil, com o princípio da legalidade e da tipicidade das infrações - como ocorre, por exemplo, na Espanha -, é possível buscar um fundamento ao princípio non bis in idem em sentido amplo quando se adverte que o Brasil ratificou, em 1992, o Pacto de San José da Costa Rica. Embora não se cumpram as exigências traçadas pelo $\S 3^{\circ}$ do artigo $5^{\circ}$ da CF para que tal Convenção adquira o status de norma constitucional, o certo é que o STF reconhece que os diplomas internacionais sobre direitos humanos ocupam um lugar específico no ordenamento jurídico brasileiro, abaixo da Constituição, mas acima da legislação ordinária. Com esse argumento, reconhece o STF que a prisão civil do depositário infiel não apresenta base legal, mesmo estando prevista no artigo $5^{\circ}$, LXVII, da CF. Ora, aplicado o mesmo argumento expendido pelo STF para o rechaço à prisão civil do depositário infiel vedada pela Convenção Americana Sobre Direitos Humanos (art. $7^{\circ}, 7$ ) ao princípio non bis in idem, seria possível afirmar que sua configuração ampla encontraria um "espaço específico" no ordenamento brasileiro, abaixo da Constituição, porém acima da legislação ambiental. E essa configuração ampla se opõe à duplicidade sancionadora - penal e administrativa -, especialmente criticável quando se toma como ponto de partida a equivalência do conteúdo dos ilícitos concorrentes.

E o princípio da proporcionalidade poderia atuar como fundamento ao non bis in idem? No Brasil, essa aplicação cumulativa pode não ensejar ofensa à proporcionalidade sempre que seja possível computar na sanção administrativa a sanção penal anteriormente aplicada. Essa compensação é vista pelo Tribunal Constitucional espanhol (STC 2/2003) como uma forma de evitar uma violação substancial ao non bis in idem. E se não for possível efetuar a referida compensação, há aplicação de uma sanção desproporcional? A esse respeito, fazse necessário observar que um dos fundamentos do non bis in idem 
como direito fundamental consiste precisamente em "evitar uma reação punitiva desproporcional", como assevera o Tribunal Constitucional espanhol na STC n. 2/2003. Todavia, na Espanha, há uma conexão do non bis in idem com o princípio da legalidade das infrações e sanções, de modo que esse excesso punitivo "rompe a garantia do cidadão de previsibilidade das sanções, pois a soma da pluralidade de sanções cria uma sanção alheia ao juízo de proporcionalidade realizado pelo legislador e materializado na imposição de uma sanção não prevista legalmente" (STC n²/2003). Além disso, aduz a doutrina espanhola que:

uma vez que o fato foi sancionado em uma primeira ocasião, a segunda ou ulteriores sanções seriam impostas por um fato que já não pode ser considerado punível no caso concreto, se esta primeira sanção foi corretamente imposta. Igualmente e sob a perspectiva da concepção da proibição de incorrer em bis in idem como um fenômeno de impossibilidade de concorrência efetiva de duas normas que tipificam infrações, pois só uma delas é aplicável, a proibição se conecta com o princípio de tipicidade das infrações, já que o fato só pode ser considerado tipificado por uma delas, restando excluída a outra. (PÉREZ MANZANO, 2005, p. 80)

Tem-se, assim, uma interpretação ampla do conteúdo do princípio da legalidade, que seria infringido em seu aspecto material quando não há previsibilidade das infrações e sanções, bem como quando se aplicam sanções desproporcionais.

O princípio non bis in idem, em seu aspecto processual, veda a pluralidade de processos, presente a tríplice identidade. É possível, portanto, a concorrência de um procedimento administrativo e de um processo penal. Algumas vezes, inclusive, o término do procedimento administrativo oferece subsídio para a propositura da correspondente ação penal. A regra da prevalência da jurisdição penal se aplica em caso de concorrência de um processo sancionador administrativo e de um processo penal. Se o processo penal conclui com uma sentença absolutória na qual não se reconhece a inexistência material dos fatos, 
é possível a apreciação destes na esfera administrativa, e não há qualquer obstáculo à eventual imposição de uma sanção extrapenal. Havendo sentença penal condenatória, a apreciação dos fatos efetuada em sede processual penal deve vincular a instância administrativa. O cômputo da sanção penal aplicada na penalidade administrativa posteriormente imposta é tido como um modo de mitigar - ou, para alguns, de afastar - o bis in idem. Não sendo possível efetuar o referido cômputo, a imposição cumulativa de uma sanção penal e de uma sanção administrativa, constatada a identidade de sujeito, fato e fundamento, representa inequívoca infração ao non bis in idem e ao princípio da proporcionalidade.

Cabe destacar que nem sempre a aplicação cumulativa de sanções penais e administrativas pela prática de um mesmo fato implicará em bis in idem. Como já salientado, pressuposto à apreciação de bis in idem é a presença de identidade de fato, fundamento e sujeito. Quanto à identidade fática, ela deve ser apreciada sob a perspectiva normativomaterial ${ }^{11}$ ou ontoaxiológica. Isso significa que é a hipótese de fato o elemento decisivo para apreciar esse pressuposto ao reconhecimento do bis in idem. Se, no plano ontológico, encontra-se determinada conduta como uma unidade de elementos objetivos e subjetivos, no plano normativo, cabe selecionar quais desses elementos devem integrar a correspondente hipótese legal. Quando o legislador penal e o legislador administrativo descrevem essa conduta empregando idênticos elementos, constata-se a identidade de fato (típico ${ }^{12}$. Ou seja, deve-se comparar o tipo penal com o tipo da infração administrativa. Haverá identidade de fato quando tais tipos coincidirem em seus elementos constitutivos. São esses elementos que permitem subsumir o

\footnotetext{
11 Nesse sentido, vide os pertinentes argumentos expendidos por Pérez Manzano (2002).

12 Cf. De León Villalba (1998, p.506 e ss.). Logo, "no contexto da proibição à dupla sanção, o fato não é o acontecimento natural identificado conforme critérios espaciais, temporais e subjetivos, mas a hipótese de fato que, como elemento da norma, pode dar lugar à aplicação da sanção" (PÉREZ MANZANO, 2002, p.101). Em outro dizer, "a norma pode reunir vários fatos em uma só ação típica ou, ao inverso, descompor um mesmo fato (natural) em várias ações típicas. A norma não leva em consideração todos os elementos naturais do fato [...] a norma só seleciona o que considera essencial" (NIETO, 2002, p. 450).
} 
fato à norma e ensejar a aplicação da sanção correspondente. Concluise, assim, que há identidade de fato típico entre a quase totalidade dos delitos constantes na Lei 9.605/98 e as infrações administrativas previstas no Decreto 6.514/08. Porém, não há identidade de fato quando o legislador penal recorre a elementos típicos que conferem ao injusto penal uma maior gravidade. É o caso, por exemplo, do artigo 54, § $2^{\circ}$, II, in fine, da Lei 9.605/98, que tipifica a causação de poluição atmosférica que "provoque a retirada, ainda que momentânea, dos habitantes das áreas afetadas, ou que cause danos diretos à saúde da população", pois, ao incorporar determinado elemento - a exigência de danos diretos à saúde da população - reforça a autonomia valorativa do direito penal do ambiente. E isso porque o artigo 62, II, do Decreto 6.514/2008, não exige o resultado de dano direto à saúde da população, referindose ao resultado de significativo desconforto respiratório ou olfativo. 0 tipo penal ambiental apresenta, portanto, um maior conteúdo de injusto e, precisamente em razão da maior gravidade material da conduta, justifica-se a intervenção jurídico-penal. O elemento que indica um maior desvalor do resultado se encarrega de conferir ao injusto penal ambiental um conteúdo específico.

Nesse sentido, também se constatará identidade de fundamento - pressuposto ao reconhecimento do bis in idem - quando a ratio legis, aferida através do exame concreto dos elementos típicos das infrações penal e administrativa, indicar que o modo de ofensa ao bem jurídico tutelado exigido por ambas é idêntico. Cabe advertir que não se trata aqui de analisar as duas normas para concluir, em caso de existência de duplicidade normativa, que houve infração ao non bis in idem, mas "de analisar as normas aplicadas efetivamente, com base nas quais foram impostas as duas sanções, para poder examinar se ambas se assentam em um pressuposto jurídico diferente ou idêntico" (PÉREZ MANZANO, 2002, p. 120) ${ }^{13}$. Logo, o exame da identidade de

13 Por conseguinte, "o fundamento de uma sanção não é o interesse ou bem jurídico protegido, mas o desvalor jurídico concreto que a conduta representa, de modo que este desvalor não vem determinado só pelo bem jurídico protegido, mas também pela forma de ataque ao mesmo através da conduta" (PÉREZ MANZANO, 2005, p. 85). 
fundamento entre sanção penal e administrativa não pode ser efetuado exclusivamente sob a perspectiva fática, mas também normativa. A diversidade de fundamento ocorre, por exemplo, quando determinada conduta é tipificada pelo legislador penal e, na configuração do referido tipo, introduz-se um elemento que indica um maior desvalor do resultado (v.g. a presença de lesão ou perigo de lesão à saúde das pessoas) ou um maior desvalor da ação (v.g. a referência aos meios ou modos de execução ou a um especial fim de agir). Assim, haverá diversidade de fundamento entre infração administrativa e delito quando aquela exigir a concorrência de perigo concreto ao ambiente (ou mesmo a bens jurídicos individuais) e este exigir a materialização de um resultado de lesão (CARVALHO, 2011). Em todo caso, apenas um exame concreto dos elementos que participam da configuração da infração administrativa e do delito ambiental permitirá aferir a diversidade de fundamento necessária para afastar a ocorrência de bis in idem.

Apesar de a legislação infraconstitucional brasileira - e da própria CF (art. 225, $\S 3^{\circ}$ ) - admitir a aplicação de sanções penais, civis e administrativas por condutas e atividades lesivas ao meio ambiente, essa afirmação não se coaduna com uma concepção ampla do non bis in idem, tal como a consagrada na Convenção Americana Sobre Direitos Humanos, ratificada pelo Brasil. E tampouco se harmoniza com o princípio da proporcionalidade. Posto que a técnica legislativa defeituosa adotada pelo legislador brasileiro praticamente equiparou a totalidade dos delitos ambientais a infrações administrativas, sempre que um determinado sujeito - pessoa física ou jurídica - realizasse uma conduta tipificada simultaneamente na esfera penal e administrativa haveria uma dupla sanção. $E$ isso não ocorreria quando o legislador, corretamente, conferisse ao injusto penal um conteúdo específico e distinto do ilícito administrativo. Quando assim for, não há identidade de fundamento e, portanto, é admissível a cumulação de sanções penais e administrativas.

Em resumo, o equívoco do legislador na configuração dos ilícitos penais não pode acarretar prejuízo ao acusado e violar princípios fundamentais. Por uma parte, a identidade de ilícitos deve conduzir a 
um conflito aparente de normas sancionadoras, a ser solucionado pelo princípio da subsidiariedade. Resolve-se o conflito de normas com a aplicação da norma penal em detrimento da administrativa (norma subsidiária). Não sendo aplicada a norma penal, é cabível a aplicação da norma administrativa. Concede-se, assim, prioridade à norma penal (norma primária). Esse conflito de normas sancionadoras sempre deve conduzir à aplicação de apenas uma delas. Sobre o princípio de subsidiariedade, cabe salientar que este encerra a ideia de que "um dos preceitos abarca exaustivamente o conteúdo de injusto e de culpabilidade do fato; esta é a verdadeira razão pela qual a lei principal pode afastar a chamada lei subsidiária" (ESCUCHURI AISA, 2004, pp. 298-299). O reconhecimento do concurso de normas ou leis se limita às hipóteses nas quais "um dos preceitos abarca por completo, exaustivamente, o desvalor jurídico-penal que representa o comportamento" (ESCUCHURI AISA, 2004, p. 436).

Por outra parte, quando os ilícitos penal e administrativo apresentarem conteúdos de injusto diferentes, isto é, quando, no ilícito penal, for possível aferir um maior desvalor da ação ou do resultado, haverá um concurso ideal de infrações e de sanções. Há diversidade de fundamento, logo, inexiste bis in idem ${ }^{14}$. Com efeito, um determinado fato foi valorado de forma distinta por dois ramos do direito, que the conferiram cada qual uma tipificação correspondente. O tipo penal foi elaborado de forma que a maior gravidade de sua consequência jurídica tivesse como pressuposto a maior gravidade de seu conteúdo de injusto. Nesse sentido, a presença de algum elemento qualificou o ilícito penal, indicando que, do ponto de vista quantitativo, ele é mais grave do que o ilícito administrativo. Portanto, não há obstáculo algum à aplicação do tipo penal e do tipo da infração administrativa.

14 Logo, quando um dos preceitos não englobar a totalidade do conteúdo de injusto e de culpabilidade do fato, "não se realiza a hipótese de fato do concurso de leis e, portanto, será necessário acudir às regras do concurso de delitos, sem que a existência de um núcleo de injusto comum implique em uma infração ao princípio non bis in idem" (ESCUCHURI AISA, 2004, p.299). Ou seja, "sempre que subsistir algum aspecto do acontecimento sem valorar, deverá ser aplicado o preceito que tenha levado em consideração esse aspecto, e isso não supõe nenhuma vulneração ao principio non bis in idem" (ESCUCHURI AISA, 2004, p.458). 
Por último, no que diz respeito à identidade de sujeito - terceiro e último pressuposto ao reconhecimento do bis in idem -, cumpre examinar a questão relativa à identidade ou não de sujeitos entre pessoa jurídica e pessoa física. No ordenamento jurídico-penal brasileiro, o artigo $3^{\circ}$, parágrafo único, da Lei 9.605/98, admite expressamente que "a responsabilidade das pessoas jurídicas não exclui a das pessoas físicas, autoras, coautoras ou partícipes do mesmo fato". Se, por exemplo, no âmbito processual penal, o administrador de uma pessoa jurídica é sancionado por um delito ambiental, nada impedirá que a pessoa jurídica seja responsabilizada penalmente, desde que a infração tenha sido cometida "por decisão de seu representante legal ou contratual, ou de seu órgão colegiado, no interesse ou benefício da sua entidade" (art. $3^{\circ}$, caput, Lei 9.605/98). Quando se instituiu a responsabilidade penal das pessoas jurídicas em seara ambiental, introduziu-se a atuação prévia de uma pessoa física como um requisito indispensável à imputação objetiva de resultados à pessoa jurídica. Logo, de acordo com o modelo instituído no Brasil, não há identidade de sujeitos - e, consequentemente, não há bis in idem - entre pessoa física e pessoa jurídica.

\section{Referências}

CARVALHO, Érika Mendes de. Limites ealternativas à administrativização do direito penal do Ambiente. Revista Brasileira de Ciências Criminais, São Paulo, v. 92, p. 299-335, 2011.

CUERDARIEZU, A. El concurso de delitos en el borrador del anteproyecto del C. P. de 1990. In: ANUARIO de derecho penal y ciencias penales. Madrid: Ministerio de Justicia, 1991. t. XLIV. p. 821-866.

DE LEÓN VILLALBA, Francisco Javier. Acumulación de sanciones penales y administrativas. Sentido y alcance del principio 'ne bis in idem'. Barcelona: Bosch, 1998.

DEL REY GUANTER, Salvador. Potestad sancionadora de la Administración y jurisdicción penal en el orden social. Madrid: Ministerio de Trabajo y Seguridad Social, 1990. 
ESCUCHURI AISA, Estrella. Teoría del concurso de leyes e de delitos: bases para una revisión crítica. Granada: Comares, 2004.

GARCÍA DE ENTERRÍA, El problema jurídico de las sanciones administrativas. Revista Española de Derecho Administrativo, La Rioja, n. 10, p. 399-430, 1976.

GARCÍA RIVAS, Nicolás. EI poder punitivo en el Estado Democrático. Cuenca: Universidad de Castilla La Mancha, 1996.

GOMES, Luiz Flávio. Pacto de San José é cada vez mais aplicado no STF. Disponível em: <http://www.lfg.com.br>. Acesso em: 11 out. 2012. GÓRRIZ ROYO, Elena. Sentido y alcance del "Ne bis in idem" respecto a la preferencia de la jurisdicción penal, en la jurisprudencia constitucional (En especial la STC 2/2003, 16 de enero). Estudios penales y criminológicos. Santiago de Compostela: Universidad de Santiago de Compostela, 2004. t. XXIX.

. El principio 'ne bis in idem' y la regla de preferencia del orden jurisdiccional penal a la luz de la STC 177/1999, de 11 de octubre. Revista de Ciencias Penales, Castelló de la Plana, v. 3, n. 1/2, p. 263$275,2000$.

HUERTA TOCILDO, Susana. Ilícito penal e ilícito disciplinario de funcionarios. In: ROMEO CASABONA, Carlos María; GRACIA MARTÍN, Luis; DÍEZ RIPOLLÉS, José Luís (Org.). La ciencia del derecho penal ante el nuevo siglo. Madrid: Tecnos, 2002. Libro Homenaje al profesor Doctor D. José Cerezo Mir.

MARTÍN RETORTILLO BAQUER, L. Sanciones penales y sanciones gubernativas. Problemas actuales de derecho penal. Salamanca: Universidad de Salamanca, 1971.

MUÑOZ CLARES, José. Ne bis in idem y derecho penal: definición, patología y contrarios. Murcia: Diego Marín, 2006.

NIETO, Alejandro. Derecho administrativo sancionador. 3. ed. Madrid: Tecnos, 2002.

PÉREZ MANZANO, Mercedes. El derecho fundamental a no padecer bis in idem y las sanciones en protección del medio ambiente. In: JORGE 
BARREIRO, Agustín (Dir.). Estudios sobre la protección penal del medio ambiente en el ordenamiento jurídico español. Granada: Comares, 2005.

. La prohibición constitucional de incurrir en bis in idem. Valencia: Tirant lo Blanch, 2002.

PRADO, Luiz Regis. Direito penal do ambiente. 4. ed. São Paulo: RT, 2012.

. Curso de direito penal brasileiro. 11. ed. São Paulo: Revista dos Tribunais, 2011. v. I.

SERRANO TÁRRAGA, María Dolores; SERRANO MAílLO, Alfonso; VÁZQUEZ GONZÁLEZ, Carlos. Tutela penal ambiental. Madrid: Dykinson, 2009.

VIVES ANTÓN, Tomás. La libertad como pretexto. Valencia: Tirant lo Blanch, 1995.

Recebido em: 16/10/12

Aprovado em: 19/12/12 